
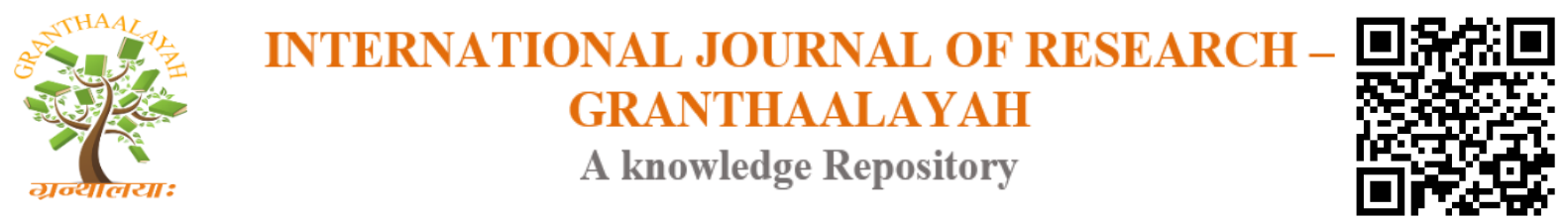

Management

\title{
ROLE OF NATIONAL RURAL LIVELIHOOD MISSION (NRLM) ON COST OF LIVING STANDARD OF THE SCHEDULED CASTE COMMUNITIES AT DHEMAJI AND LAKHIMPUR DISTRICT OF ASSAM
}

\author{
Dr. Diganta Kumar Das *1 \\ ${ }^{* 1}$ Assistant Professor, Department of Accountancy, Lakhimpur Commerce College, North \\ Lakhimpur, Assam, India
}

\begin{abstract}
Motivation/Background: The financial aspects are considered as an integral part for development of rural areas in every nation. Small financial helps can defiantly improve the living standard of the poor. Here the role of microfinance is crucial. Through microfinance the poor and needy people can fulfil their day to day and small economic and financial requirements upto certain extend. In India it is seen that most of the people lives in the rural areas are below the poverty line and finance to these group is very much essential. Moreover, the vulnerable groups are more deprived of their basics needs particularly the SCs and the STs. Thus, an effort has been made by the researcher to study the pros and cons of NRLM and its impact on economic condition of poor SC people living in the rural areas at Dhemaji and Lakhimpur district of Assam through this paper.

Method: For that purpose, both the primary and secondary data have been used. For collecting the primary data, a total number of 140 (7 X 10 X 2=140) respondents from 70 SHGs had randomly selected comprising of 10 SHGs from the seven Development Blocks and from each sample SHGs 2 members were selected.

Results and Conclusions: Study revealed that inspite of facing the problems like marketing, transportation, flood and proper management and training of the group, the SHGs are functioning well in terms of improvement of food security and cost of living standard of the SC member's household in the area under study.

Keywords: Economic Impact; Rural Livelihood; SC Communities and Self-Help-Groups.

Cite This Article: Dr. Diganta Kumar Das. (2020). "ROLE OF NATIONAL RURAL LIVELIHOOD MISSION (NRLM) ON COST OF LIVING STANDARD OF THE SCHEDULED CASTE COMMUNITIES AT DHEMAJI AND LAKHIMPUR DISTRICT OF ASSAM." International Journal of Research - Granthaalayah, 8(4), 119-126. https://doi.org/10.29121/granthaalayah.v8.i4.2020.16.
\end{abstract}




\section{Introduction}

Improvement in the lives of poor people is the main aim of every rural development programmes. The problems of poverty in rural areas are always associated with the vulnerable classes. The main reasons behind such backwardness are due to lack of access for the poor to the basic services like education, health, sanitation, etc. The economic dependence, rapid increase in population after independence, disempowerment and lack of access to credit are also an added to the poor vulnerable (Jothi, 2010). Financial benefits through microfinance to the poor peoples are the major solutions for economic upliftment of these communities. The rural economies within which the majority of poor people live and work are characterized by numerous small transactions (Panda, 2008). Since the inception of SGSY, it is seen that the programme has not attracted the needy people for the optimum economic development particularly at flood affected rural areas in India. In this regard micro finance through SHGs is considered as an important tool for providing and developing the financial needs of the rural people. Through microfinance the poor and needy people can fulfil their day to day and small economic and financial requirements upto certain extend. National Rural Livelihood Mission (NRLM) which was come into force from $1^{\text {st }}$ April 2012 which promote the formation of women SHGs and thereby providing financial assistance to take up the economic activities for their livelihoods.

Income generation and improvement in cost of living standard could only be possible through microfinance which has now concentrated by the government in every developing country like India (Das D.K., 2019). Thus through the present survey an attempt has been made to understand the role of NRLM for the improvement of the living standards of Scheduled Caste (SC) Communities where majority of such peoples still live in the flood affected rural areas like Dhemaji and Lakhimpur district of Assam.

\section{Objectives of the Study}

The main objectives of the present study are:

1) To study the socio-economic background of the respondents;

2) To study the SHGs impact on SC communities for improvement in their cost of living standards; and

3) To study the different constrains affected the working of SC member SHGs under the study area.

\section{Methods Adopted for the Study}

Necessary data were gathered from both the sources of primary and secondary. A field survey through filled in questionnaire was conducted for gathering the primary data. The secondary data were collected from different journals, books, relevant documents, newspapers and magazines, records of Non-Governmental Organisations (NGOs), Institute of Co-operative Management (ICM) etc. After careful examination, it was decided to follow three stage sampling method. At the first stage, four development blocks (Namely Telahi, Boginodi, Lakhimpur and Ghilamora) in Lakhimpur District and three development blocks (namely Dhemaji, Bordoloni and Machkhowa) have been purposivly selected. Secondly, 10 SHGs were taken randomly from every sample blocks and at the third stage, from each sample SHGs 2 SC members were randomly selected as 
respondents. Thus $140(7 \times 10 \times 2=140)$ respondents were selected for the purpose of the present study. Statistical tools like percentages, simple average, were adopted for analyzing the data under study.

\section{Result from the Analysis}

Findings of the present investigation were presented under the following heads:

1) Socio-economic Profile of the respondents.

2) Impact of SHG on Economic condition of the respondents.

3) Problems faced by the respondents.

\subsection{Socio-economic Profile of the Respondents}

The observations from the field survey in respect to the socio-economic background of the respondents were:

1) Majority of the respondents i.e. 64.3 percent were middle aged (31 to $50 \mathrm{yrs}$.), while 33.6 per cent were young (18 to $30 \mathrm{yrs}$ ) and remaining i.e. 2.1 per cent were old aged.

2) 26.4 per cent respondents were literate functionally, 21.4 per cent respondents had high school education, 19.3 per cent had primary education, 17.9 per cent had middle school education, and only 7.9 per cent were illiterate and only 6.4 per cent of them received college level education.

3) 87.1 percent of the respondents were found married, 9.3 per cent of the respondents were unmarried and 3.6 per cent were reported as widows.

4) More than half i.e. 52.9 percent of the respondents were reported to be other backward caste followed by general community (22.9 percent), Scheduled Tribe (13.6 percent) and Scheduled Caste (10.7 percent).

5) 31.4 per cent of them belonged to high income category, followed by respondents belonging to semi-medium income category (30.0 percent), medium income category (29.3 percent) and only 9.4 per cent of them belonged to low income category which has been observed during the field survey and it has happened only because of joining the members to SHGs. Similar study has been done by Das D.K (2016).

\subsection{Impact of SHGs on Economic Condition of the Respondents}

\subsubsection{SHGs' Impact on Food Security of SC Communities}

The researcher has attempted to study the food consumption habits of SC communities under the study area after joining the SHGs and the relevant data were presented in Table 1 below:

Table 1: Annual Food Consumption of the Respondents

\begin{tabular}{|l|l|c|c|}
\hline Sl. No. & Variables & $\begin{array}{c}\text { Before joining SHGs } \\
\text { (Amount in ₹) }\end{array}$ & $\begin{array}{c}\text { After joining SHGs } \\
\text { (Amount in ₹) }\end{array}$ \\
\hline 1 & Expenses on Food Grains & 75165.57 & 90527.11 \\
\hline 2 & Expenses on Fruits & 35379.35 & 92574.01 \\
\hline 3 & Expenses on Pulses & 49554.97 & 102384.70 \\
\hline 4 & Expenses on Vegetables & 49546.83 & 89748.23 \\
\hline
\end{tabular}




\begin{tabular}{|l|l|c|c|}
\hline 5 & Expenses on Non-Veg Items & 62954.33 & 150989.94 \\
\hline 6 & Expenses on Milk and milk products & 48210.58 & 148669.54 \\
\hline 7 & Expenses on Cooking Gas \& Oil & 14643.74 & 20486.54 \\
\hline 8 & Expenses on Misc food items & 41486.84 & 55104.19 \\
\hline Total Expenses on Food Items & $\mathbf{4 2 0 9 4 2 . 2 0}$ & $\mathbf{3 7 6 9 4 2 . 2 1}$ \\
\hline Average Food Consumption & $\mathbf{5 2 6 1 7 . 7 7}$ & $\mathbf{2 6 9 2 . 4 4}$ \\
\hline
\end{tabular}

Source: Compiled from Field Survey

The impact SHGs on annual food consumption the SC members were found satisfactory. A tremendous improvement has been seen in consumption of milk and milk products which was followed by consumption of fruits, non-vegetable items, consumption of pulses, etc. After joining the groups, most of SHG members were prefer LPGs as a replacement for wood for their cooking in the households which was found under the study area. Similar findings have been made by Das D.K (2016).

\subsubsection{SHGs Impact on Living Condition of SC Communities}

The living standard of the SC communities under the study area was judge and analyzed by the researcher in relation to the annual Non-Food consumption of the respondents. The relevant data in this regard are presented in Table 2 as below:

Table 2: Annual Non-Food Consumption of the Respondents

\begin{tabular}{|l|l|c|c|}
\hline Sl. No. & Variables & $\begin{array}{c}\text { Before joining } \\
\text { SHGs } \\
\text { (Amount in ₹) }\end{array}$ & $\begin{array}{c}\text { After joining } \\
\text { SHGs } \\
\text { (Amount in ₹) }\end{array}$ \\
\hline 1 & Expenses on Health Expenses & 45387.39 & 72512.91 \\
\hline 2 & Expenses on Clothing & 82126.86 & 87428.50 \\
\hline 3 & Expenses on Festivals & 72727.62 & 214191.78 \\
\hline 4 & Expenses on Education for children & 20712.98 & 47420.54 \\
\hline 5 & Expenses on Electricity & 4312.00 & 9884.49 \\
\hline 6 & Expenses on Toddy \& Alcohols & 20950.40 & 9356.21 \\
\hline 7 & Expenses on Beedi-Cigarettes, Pan etc. & 11511.49 & 2766.55 \\
\hline 8 & Other Expenses & 10658.08 & 21277.51 \\
\hline $\begin{array}{l}\text { Total Expenses on Non-Food Items (Living } \\
\text { Standards) }\end{array}$ & $\mathbf{2 6 6 5 5 7 . 3 0}$ & $\mathbf{4 6 4 8 3 8 . 4 8}$ \\
\hline \multicolumn{2}{|l|}{ Average Non-Food Consumption } & $\mathbf{1 9 1 7 . 0 5}$ & $\mathbf{3 3 2 0 . 2 7}$ \\
\hline
\end{tabular}

Source: Compiled from Field Survey

The study found about a significant impact of SHGs on consumption of non-food items among the $\mathrm{SC}$ communities under the study area. Among the non-food items the SC members were expended more on festivals which was followed by electricity, education of the childrens, other expenses etc. A significant improvement in regards to reduction in consumption of toddy \& alcohol, beedi $\&$ cigarette, pan etc. among the SC communities has been seen under the study area. It was possible only because of involvement of SC women members in social activities like creating awareness on no tobacco, Swatchha Bharat Abhiyan etc. under the study area. Similar researches have been done by Bhuvan, 2007, Nalini \& et al, 2013 and findings made by Das D.K (2016). 


\subsubsection{Impact of SHGs on Housing Conditions of the Respondents}

The housing condition of the households of the SC member under the study area has also been analyzed by the researcher in the present study. The Table 3 shows the position of housing condition of the respondents as on survey date from the date of SHG formation.

Table 3: Respondents according to type of Housing Conditions

\begin{tabular}{|l|l|c|c|c|c|}
\hline \multirow{2}{*}{$\begin{array}{l}\text { Sl. } \\
\text { No. }\end{array}$} & Housing Status & \multicolumn{3}{|c|}{ Type of House } & \multicolumn{1}{c|}{$\begin{array}{c}\text { Total no. of } \\
\text { Respondents Household }\end{array}$} \\
\cline { 3 - 5 } & Pucca & $\begin{array}{l}\text { Semi- } \\
\text { Pucca }\end{array}$ & Katchha & \\
\hline 1 & At Present & $31(22.14)$ & $74(52.86)$ & $35(25.00)$ & $\mathbf{1 4 0 ( 1 0 0 . 0 0 )}$ \\
\hline 2 & $\begin{array}{l}\text { At the time of } \\
\text { formation of SHGs }\end{array}$ & $11(7.86)$ & $30(21.43)$ & $98(70.00)$ & $\mathbf{1 4 0 ( 1 0 0 . 0 0 )}$ \\
\hline
\end{tabular}

Source: Compiled from Field Survey

Note: The figures given in parentheses indicate percentages of no. of Tribal Members.

From the above Table 3 it is observed that the Katchha houses of the households of the tribal respondents have declined gradually in the study area from $98(70.00 \%)$ to $35(25.00 \%)$ households particularly after joining the SHGs. The Pucca and semi pucca houses of the respondents have increased tremendously from 11 to 31 households and from 30 to 74 households respectively during the period. Similar findings have been made by Das D.K (2016).

\subsection{Different Constraints Faced by the Respondents}

There are as many as eight major problems that have been faced by the sample SHGs in smooth functioning of their groups. When asked about the magnitude of different problems faced by the SHGs, a maximum of 36 sample SHGs replied about the management problem which is very much affected the growth of those SHGs in the district. Table 4 shows the different problems which have been faced by the sample SHGs in the districts during the period of the study.

Table 4: Different Constrains faced by the Sample SHGs under study (Multiple Responses)

\begin{tabular}{|l|l|c|c|}
\hline $\begin{array}{l}\text { Sl. } \\
\text { No. }\end{array}$ & Types of Problems & $\begin{array}{c}\text { No. of Responses from } \\
\text { sample SHGs }\end{array}$ & Percentage \\
\hline 1 & Management problem & 25 & 35.71 \\
\hline 2 & Problems in marketing of product & 17 & 24.29 \\
\hline 3 & Problems in maintenance of accounts & 26 & 37.14 \\
\hline 4 & Procuring credit from the bank & 5 & 7.14 \\
\hline 5 & Low availability of input & 3 & 4.29 \\
\hline 6 & Difficulties in production of finished goods & 2 & 2.86 \\
\hline 7 & $\begin{array}{l}\text { Problems from implementing agency/other } \\
\text { departments }\end{array}$ & 1 & \\
\hline 8 & Problem in undertaking of training & 3 & 4.29 \\
\hline
\end{tabular}

Source: Compiled from field survey. 
The different problems faced by the respondents in the districts were

1) Management problem is the main problem disturbing the growth of SHGs in the district. Management problems may arise due to following reasons:

- Selection of Group leader.

- Problem of attendance of the members in different group meetings.

2) Marketing Problem involves the followings

- As observed 62.0 per cent SHGs sell their product at their own village. Only 20 per cent SHGs are selling their product at nearest town.

- The dependence on local markets is due to lack of ability to present their products in a more acceptable way in distant and competitive markets, non -availability of access to market infrastructure as well as technology for higher value addition, and change of product usage.

3) Accounts Keeping Problem

For success of an SHG proper maintenance of accounts is very much necessary. As reported, 37.14 per cent SHGs have opined about their poor knowledge of accounts keeping which creates difficulties in proper recording of all financial transactions in a same place of books. It is due to the lack of training on accounts keeping by most of the respondents in the study area. Moreover the educational background of most of the respondents is primary fail or even low, which creates difficulties in understanding the accounting procedure among these SHG members.

\section{4) Procuring Credit from the Bank}

Due to complicated bank procedure for availing loan, 7.14 per cent of the SHGs have been facing the problem of procuring credit from banks in the district. As a result the members of the SHGs have been facing difficulties to communicate things effectively with the bank officials for approaching them for loan and thus there is a delay in sanctioning the loan to some of the SHGs.

\section{5) Low Availability of Input}

Due to shortage of availability of fund, most of the sample SHGs in the district is not able to purchase the raw materials in time. Moreover, with the low rate of return on investment it is not possible to purchase good quality raw material particularly in case of handloom \& handicraft, duckery, poultry, fishery, mushroom and other food processing activities by the SHG members. Low amount of return from the economic activities arises mainly because of not taking these activities fully on commercial basis by the members of SHGs operating in the districts.

\section{6) Other Constrains of the Sample SHGs}

The other problems that have been faced by the SHGs in the district are the production problem which has arisen mainly because of flood and improper road connectivity. As a result the hard working people living in the flood affected areas could not produce the finished products upto their expectation as demanded by the market forces. On the other hand lack of proper guidance and support from the implementing agencies and other government departments causes slow progress of SHGs operated under the study districts.

\section{Recommendations}

Analysis of the present study reveals the following suggestions:

1) More emphasis should be given by the government on organizing orientation programmes and workshops in the rural areas for entrepreneurship development and the educated unemployed youths will be the targeted groups to these workshops.

2) Focussed should be made on providing informal education to the rural women. It will help the women for presenting their capabilities in regards to rural development. 
3) Government should create environment for proper marketing of the SHG's products by organizing melas, expos etc.

\section{Conclusions}

The NRLM has played a significant role for the development of the rural women through formation of SHGs. Major cross-section can have been benefited if micro finance sector will grow in its fastest pace. From the analysis it can be concluded that numbers of members have started savings only after joining the groups in the district under study. The present study concludes that after joining the SHGs, the problems that have been faced by the SC members of these SHGs were not reduced yet fully. Less orientation and lack of proper training on skill development to all the members of the SHGs in Dhemaji and Lakhimpur district were the main reasons behind these problems (Das, D.K. 2019). The observation of the present study also showed that SHGs are functioning well in terms of food security and improvement in living standard of the member's household in the area under study. There was a lot of impact on consumption of food items and non-food items on the SHG members. In the case of nonfood items, all the items were showing satisfactory, except expenditure on toddy and alcohol and beedi and cigarette, pan etc. (Nalini, M.S., \& et all, 2013 and Das. D. K. 2016).

\section{Acknowledgement}

We acknowledge our heartiest thanks to IMPRESS-ICSSR, New Delhi for providing us a support for research investigation on socio-economic conditions of the Scheduled Caste Communities in rural Assam.

\section{References}

[1] Bhuvan, I. B., Performance of micro-finance providers in Karnataka, Unpublished MBA (Agribusiness), Thesis, University of Agricultural Science, Dharwad (India), 2007.

[2] Borman, Ratan and Chanu, A. Ibemcha, A study on some issues of microfinance programme in India, DGCCS's Journal of Commerce, vol. VI, no. 1, 2009, 58-68.

[3] Census data of Lakhimpur District 2011, Country Focus: India: Assam: Lakhimpur District: District Profile, retrieved from http://lakhimpur.nic.in/profile.htm.

[4] Das B.C., Performance of SGSY-SHGs Linked to RRBs in Karnataka, Economic Affairs, Vol. 55, No. 3\&4, December 2011, 207-216.

[5] Das D. K., A study on the Constraints faced by the Scheduled Caste (SC) Women under National Rural Livelihoods Mission (NRLM) in Lakhimpur District of Assam, International Journal of Research in Commerce, Economics \& Management (IJRCM), Vol. 9, Issue No. 01, January 2019, 20-24. Retrieved from https://ijrcm.org.in/article_info.php?article_id=8844

[6] Das D. K., Microfinance and Its Impact on Tribal Communities (A study on food consumption, living standard and the socio-economic constrains of Tribal SHG members at Lakhimpur district of Assam), Imperial Journal of Interdisciplinary Research (IJIR) Vol.2, Issue-2, January 2016, 18, retrieved from https://www.onlinejournal.in/IJIRV2I2/001.pdf

[7] Das D. K., Microfinance through Self Help Groups and its impact on Socio_economic development of Tribal Communities: A case study of Lakhimpur District of Assam, Ph.D thesis submitted to Dibrugarh University, Dibrugarh, 2016.

[8] Das S.K., Expansion of Micro-Financing through Swarnajayanti Gram Swarojgar Yojana: Experience in West Bengal, Economic Affairs, Vol. 55, No. 2, June 2010, 180-186. 
[9] Dutta Swapan, Role of women in rural economic development through Self Help Groups: A case study in Lakhimpur district of Assam, Contemporary Research in India, Vol. 2, Issue 2, June 2012, 202-205.

[10] Jothi V.N., Socio-Economic Impact: Microfinancing of SHGs, SCMS Journal of Indian Management, 2010, 91-103.

[11] Mansuri B.B., Microfinancing through Self-Help-Groups- a case study of Bank Linkage Programme of NABARD", APJRBM, Sri Krishna International Research \& Educational Consortium, Vol. 1, issue. 3, December 2010, 141-150.

[12] Nalini, M.S. \& et al., Impact of SHGs on rural economy in North East Karnataka, Karnataka Journal of Agricultural Science, Vol. 26, No. 2, 2013, 220-223.

[13] Mohd. Najmul Islam, The microfinance guarantee for financial inclusion: Evidence to support in India, Indian Journal of Commerce \& Management Studies, Vol. III Issue 1, January 2012, 130134.

[14] Panda Debadutta Kumar, Self Help through Microfinance: A Paradigm Shift in Orissa, India, International Journal of Rural Studies (IJRS), vol. 15 no. 1, Article 8, April 2008, 1-7.

[15] Singh K, Rural development, principles, policies and management, Sage Publication, New Delhi, 2001.

[16] Singh S., Kaur A. and Gill T. K., Role of Swarnajayanti Gram Swarozgar Yojana (SGSY) in socioeconomic development in Rural Punjab, IASSI Quarterly, special issue, Journal of Association of Social Science Institution, 2009, 42-54.

[17] Tangirala H.S.K., SHG is a tool of economic development of cooperatives and its members, Kurukshetra, Journal of Ministry of Rural Development, Vol. 57, No. 2, December 2008, 22-24.

*Corresponding author.

E-mail address: diganta.das1981@gmail..com 